\title{
New Record of Terminal Pleistocene Elk/Wapiti (Cervus canadensis) from Ohio, USA
}

BRIAN G. REDMOND', Department of Archaeology, Cleveland Museum of Natural History, Cleveland, OH, USA; DAVID L. DYER, Ohio History Connection, Columbus, OH, USA; and CHARLES STEPHENS, Sugar Creek Chapter, Archaeological Society of Ohio, Massillon, OH, USA.

ABSTRACT.The earliest appearance of elk/wapiti (Cervus canadensis) in eastern North America is not thoroughly documented due to the small number of directly dated remains. Until recently, no absolute dates on elk bone older than 10,000 ${ }^{14} \mathrm{C}$ yr BP $(11,621$ to 11,306 calibrated years (cal yr) BP) were known from this region. The partial skeleton of the Tope Elk was discovered in $\mathbf{2 0 1 7}$ during commercial excavation of peat deposits from a small bog in southeastern Medina County, Ohio, United States. Subsequent examination of the remains revealed the individual to be a robust male approximately 8.5 years old at death. The large size of this individual is compared with late Holocene specimens and suggests diminution of elk since the late Pleistocene. Two accelerator mass spectrometry (AMS) radiocarbon assays on bone collagen samples taken from the scapula and metacarpal of this individual returned ages of $10,270 \pm 30{ }^{14} \mathrm{C} \mathrm{yr} \mathrm{BP}$ (Beta-477478) $(12,154$ to 11,835 cal yr BP) and 10,260 \pm 30 ${ }^{14} \mathrm{C}$ yr BP (Beta-521748) $(12,144$ to $11,830 \mathrm{cal}$ yr BP), respectively. These results place Cervus canadensis in the terminal Pleistocene of the eastern woodlands and near the establishment of the mixed deciduous forest biome over much of the region. This early temporal placement also situates this early elk as closely following the last representatives of now-extinct megafauna such as the American mastodon (Mammut americanum) and contemporary with the Late Paleoindian inhabitants of the region.

OHIO J SCI 121(2):2-14

\section{INTRODUCTION}

The earliest presence of elk/wapiti (Cervus canadensis) in the eastern woodlands of North America is not thoroughly documented. In fact, there are virtually no records of directly dated elk specimens in North America, south of Beringia, that are more than 10,000 radiocarbon years in age (O'Gara and Dundas 2002: p. 77; Burns 2010: p. 39). Most specimens that exceed this date threshold were aged using indirect methods involving biostratigraphic contexts or direct dating of associated geological or archaeological deposits (Table 1). The recent discovery of a partial elk skeleton in northeast Ohio (a.k.a. the Tope Elk) provides new evidence for the presence of this species in at least the lower Great Lakes region by the terminal Pleistocene, referred to herein as the period between 12,000 to $10,000{ }^{14} \mathrm{C}$ yr BP (ca. 13,800 to 11,500 calibrated years (cal yr) BP). This paper describes the Tope Elk remains and direct radiocarbon dating, and then discusses the importance of this find to understand the timing of

${ }^{1}$ Address correspondence to Brian Redmond, Department of Archaeology, Cleveland Museum of Natural History, 1 Wade Oval, Cleveland, OH 44106-1767, USA.

Email: bredmond@cmnh.org the dispersal of elk into eastern North America and its environmental context in the eastern woodlands.

\section{BACKGROUND}

The Tope Elk was discovered during the commercial excavation of peat from a 7.2 ha (17.8 acre), unnamed bog located $4.2 \mathrm{~km}$ (2.6 miles) southwest of downtown Wadsworth, Ohio, lat $41^{\circ} 00^{\prime} 28.1^{\prime \prime N}$, long $81^{\circ} 46^{\prime} 25.4^{\prime \prime W}\left(41^{\circ} 0.468^{\prime} \mathrm{N}\right.$, $\left.81^{\circ} 46.423^{\prime} \mathrm{W}\right), 293 \mathrm{~m}$ AMSL (Fig. 1). Theboneswere reportedly recovered between 2.5 to $3.0 \mathrm{~m}$ (8.2 to 9.8 $\mathrm{ft}$ ) below the surface of the bog, and were lying on a clay marl substrate. In September 2017, Stephens reported the discovery to Redmond. The remains were initially thought to be stag-moose (Cervalces scotti), but further examination revealed them to be elk (Cervus canadensis). The Tope family loaned the recovered parts of the skeleton to the Cleveland Museum of Natural History $(\mathrm{CMNH})$ for study and preliminary documentation by Redmond. Later, title to the collection was permanently transferred to CMNH under Accession Number 2017-13.

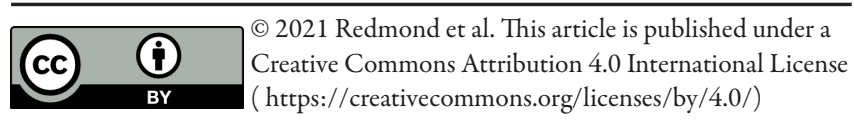


Two early Holocene elk skeletons from Ohio were previously reported: the Cranberry Prairie Elk from Mercer County (Murphy et al. 1985) and the Lattimer Elk from Champaign County (Hansen 1996) (Fig. 1). The site of the Lattimer Elk skeleton has yielded more remains in subsequent years. Ten more finds have been made, consisting of one or more bones, which have been deposited into the Natural History collection of the Ohio History Connection (OHC) in Columbus, Ohio, United States. None of these later donations have been radiocarbon dated.

Elk from later in the Holocene are represented by 2 incomplete skeletons found in Silver Lake (Fig. 1), Logan County, Ohio, in 1960 (Goslin 1961). A third elk skeleton, housed with the original 2 at the OHC, may be a specimen that was recovered from the lake at a later date. The Silver Lake Elk were not radiocarbon dated, but Hansen (1996) concludes they may only be a few hundred years old based on their stratigraphic position near the top of the lake sediments (following Ogden 1966). The skeletons were found in shallow water after they were noticed by youth from a lakeside camp (Goslin 1961), rather than recovered from the well-studied and dated sediment from Silver Lake as documented by Gill et al. (2012). Elk were common in later
pre-European contact Ohio as demonstrated by the plethora of remains preserved in archaeological faunal assemblages curated in museums throughout Ohio. The species was extirpated from Ohio in 1837 (Kirtland 1838).

\section{METHODS}

The bones of the Tope Elk were initially inventoried and photographed by Redmond at CMNH. Individual elements were examined for evidence of excavation damage, pathology, trauma, and ancient human modifications (e.g., butchering marks). In October 2017, a $2.28 \mathrm{~g}$ sample of cortical bone from the left scapula of the specimen was submitted to Beta Analytic ${ }^{\circledR}$ Inc., Miami, Florida, for accelerator mass spectrometry (AMS) radiocarbon dating of collagen. All calibrated radiocarbon dates are reported at the $2 \sigma(95 \%)$ confidence level and were calculated using CALIB software version 7.0.4 (Stuiver and Reimer 1993) and the IntCal13.14c calibration curve. Student's $t$ statistical comparisons of radiocarbon dates were also calculated using CALIB 7.0.4 software.

In October 2018, the elk bones were loaned to Dyer for formal inventory and analysis in the Natural History section of the OHC in Columbus. The identification of the skeleton was confirmed

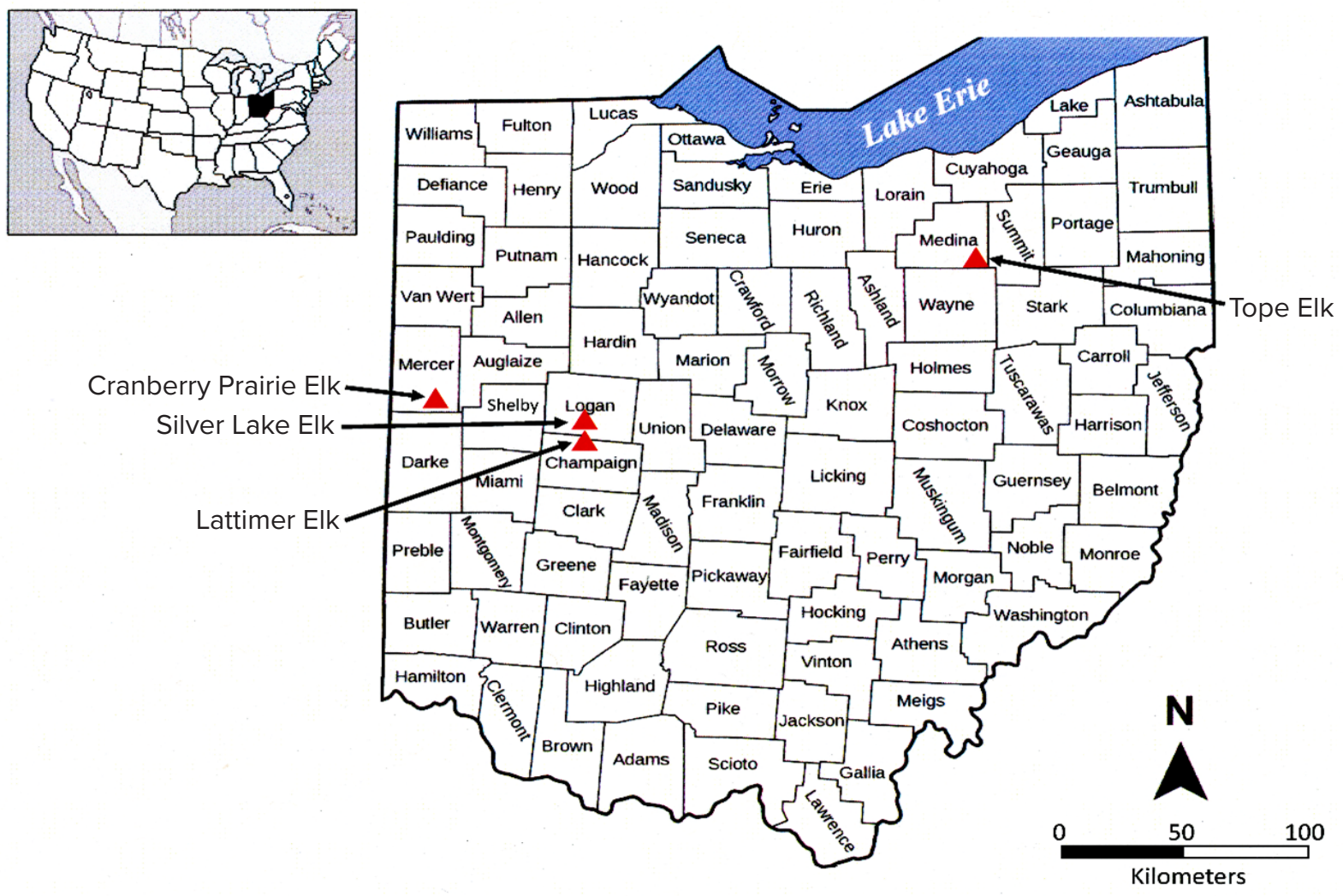

FIGURE 1. Locations of Tope Elk and other Ohio elk specimens discussed in the text 
by comparison to known elk specimens and observation of the maxillary canine alveolus. The bones were then identified to element and the following information noted: side present, portion, age, taphonomy, and measurements. The age of the individual was estimated by examining multiple criteria including epiphyseal fusion, tooth wear, and alveolar bone resorption. The sex of the elk was confirmed by the presence of an antler tine, and the antler also helped to estimate the season of death as a winterkill. The specimens were then returned to CMNH in March 2019 for permanent curation. A second bone sample, consisting of a 1.0 $\mathrm{g}$ fragment of the left metacarpal, was submitted to Beta Analytic in March 2019 for AMS dating.

\section{RESULTS}

A complete inventory and morphometrics of the Tope Elk remains are listed in Table 2 and Table 3, respectively. A total of 21 skeletal elements were recovered from the bog site and preservation is good. No ancient cultural modifications, such as stone tool cut marks or other signs of human butchering, are evident on the skeleton. Also, no rodent or carnivore tooth marks were found, indicating that the skeleton was not exposed on the surface for a long period before burial or submersion in water. Minor breakage is present on several of the bones, including the innominate, scapula, sacrum, sixth cervical vertebra, and third thoracic vertebra. None of this breakage follows the pattern of typical fragmentation of long

Table 1

Indirectly dated late Pleistocene elk remains from eastern North America

\begin{tabular}{|c|c|c|c|c|}
\hline Site name & Analysis unit & Age range $^{+}$ & Dating method & Reference \\
\hline Baker Bluff Cave, TN & $5-6 \mathrm{ft}$. level & $\begin{array}{r}11,640-10,560{ }^{14} \mathrm{C} \text { yr BP } \\
(14,076-13,013 \text { cal yr BP })\end{array}$ & ${ }^{14} \mathrm{C}$ dated strata & $\begin{array}{l}\text { Guilday et al. } \\
\text { 1978: p. 53-54 }\end{array}$ \\
\hline Big Bone Lick, KY & Zone B & 11,000 yr BP-modern & Biostratigraphy & $\begin{array}{l}\text { Schultz et al. } \\
\text { 1963: p. 1168; } \\
\text { Williams et al. } 2018\end{array}$ \\
\hline Clark's Cave, VA & Entrance 2 & $20,000-11,000$ yr BP & Biostratigraphy & Guilday et al. 1977 \\
\hline Duncker Muskox, IN & Assemblage & $15,000-11,000$ yr BP & Biostratigraphy & Lyon 1931 \\
\hline Hiscock, NY & Unit B & $\begin{array}{c}9,340 \pm 100{ }^{14} \mathrm{C} \text { yr BP } \\
(10,788-10,248 \text { cal yr BP })\end{array}$ & $\begin{array}{l}{ }^{14} \mathrm{C} \text { date on } \\
\text { wood }\end{array}$ & $\begin{array}{l}\text { Laub et al. 1988: } \\
\text { p. } 73\end{array}$ \\
\hline $\begin{array}{l}\text { Hollidaysburg Fissure, } \\
\text { PA }\end{array}$ & Assemblage & 11,000 yr BP & $\begin{array}{l}\text { Amino acid } \\
\text { racimization }\end{array}$ & $\begin{array}{l}\text { Fonda and } \\
\text { Czebieniak } 1986\end{array}$ \\
\hline Hosterman's Pit, PA & Assemblage & $\begin{array}{c}9,240 \pm 1,000{ }^{14} \mathrm{C} \text { yr BP } \\
(12,981-8,199 \text { cal yr BP })\end{array}$ & ${ }^{14} \mathrm{C}$ dated strata & Guilday 1967 \\
\hline $\begin{array}{l}\text { Meadowcroft } \\
\text { Rockshelter, PA }\end{array}$ & Stratum IIA & $\begin{array}{r}14,255-10,850{ }^{14} \mathrm{C} \text { yr BP } \\
(22,025-13,063 \text { cal yr BP })\end{array}$ & $\begin{array}{l}\text { Six }{ }^{14} \mathrm{C} \text { dates on } \\
\text { cultural features }\end{array}$ & $\begin{array}{l}\text { Adovasio et al. } \\
1978\end{array}$ \\
\hline Paw Paw Cove, MD & $\begin{array}{l}\text { Overlying } \\
\text { paleosol }\end{array}$ & $\begin{array}{l}17,820 \pm 170{ }^{14} \mathrm{C} \text { yr BP } \\
(22,005-21,040 \text { cal yr BP })\end{array}$ & $\begin{array}{l}{ }^{14} \mathrm{C} \text { dated } \\
\text { stratum }\end{array}$ & $\begin{array}{l}\text { Eshelman et al. } \\
2018\end{array}$ \\
\hline $\begin{array}{l}\text { Raddatz Rockshelter, } \\
\text { WI }\end{array}$ & Level 13-15 & $\begin{array}{l}11,602 \pm 300{ }^{14} \mathrm{C} \text { yr BP } \\
(14,121-12,801 \mathrm{cal} \mathrm{yr} \mathrm{BP})\end{array}$ & $\begin{array}{l}{ }^{14} \mathrm{C} \text { dates on } \\
\text { cultural strata }\end{array}$ & Cleland 1966 \\
\hline Wormhole Cave, WV & Assemblage & $51,650 \pm 4,110{ }^{14} \mathrm{C}$ yr BP* & $\begin{array}{l}{ }^{14} \mathrm{C} \text { date on } \\
\text { Neotoma floridana }\end{array}$ & $\begin{array}{l}\text { Semken et al. } \\
2010\end{array}$ \\
\hline
\end{tabular}

${ }^{+}$All calibrated radiocarbon dates are reported at the $2 \sigma$ confidence level and were calculated using CALIB software version 7.0.4 (Stuiver and Reimer 1993).

* Calibration not possible. 
bones resulting from human butchering as described by Gustafson and Wegener (2004). Much of this damage is recent, possibly associated with discovery or excavation of the specimen. Some of the breakage is older, however, as indicated by staining of the fracture surface. The straight edges and the lack of spiral fractures indicate that the older fractures occurred when the bone was dry rather than fresh (Johnson 1985). None of the long bones in this partial skeleton exhibited any type of breakage.

The recovered bones of the Tope Elk are derived from diverse parts of both the axial and appendicular regions of the skeleton (Table 2). They include elements from both the right and left sides of the animal, but only in the maxilla are both right and left sides present. Most of the vertebrae are missing from the collection as well as nearly all the leg bonesexcept for the left metacarpal, right femur, and 3 phalanges. This assemblage appears to be an almost random selection of skeletal elements, which may indicate that the skeleton was highly disarticulated prior to, or during, deposition. Alternatively, this may be due to the use of a backhoe for excavation, during which additional bones were missed.

\section{Age, Sex, and Size Estimates}

The Tope Elk is a male based on the presence of an antler fragment. Antlers are usually found exclusively on males in the members of the family Cervidae (excluding Rangifer, where females have antlers, albeit smaller). The remains are determined to be those of a prime-age adult - clearly older than 4 years and approximately 8.5 years old-based on the following 6 reasons:

1) The antler fragment from the sample is a large tine rather than part of a main beam, and measures $459 \mathrm{~mm}$ (18.1 in) long. The tines tend to be more flattened in cross section, in contrast to the more rounded main beam. It is difficult to age an elk from the antlers (Murie 1951). Also, Willis et al. (2009) state that elk 3.5 years and older cannot be accurately aged from the antlers. The tine from the Tope Elk is, however, significantly larger than the tines from the Lattimer Elk, the latter being a 3 to 3.5-year-old male as determined by the tooth eruption sequence of the mandible following Quimby and Gaab (1952) and Jensen (1999). Thus, the Tope Elk must be at least 4 years old, and most likely much closer to the higher end of the range (8.5+ years), as defined by the tooth wear analysis (below).
2) Pronounced muscle attachment sites (entheses) are seen on many of the skeletal elementsindicating a robust, prime-aged individual. Such entheses were especially noted on the femur, innominate, metacarpal, scapula, vertebrae, and ribs. The entheses were much more pronounced than on the Lattimer Elk or on the Silver Lake Elk specimens, the latter of which are the same chronological age as the Tope Elk.

3) The Tope Elk exhibits complete epiphyseal fusion, also indicative of a full-grown adult. Elements that show complete fusion, with obliterated epiphyseal lines, are the distal femur, distal metacarpal, distal scapula, proximal second phalanx, and bodies of the vertebrae. There is a paucity of literature on epiphyseal fusion rates in elk; however, Lyman (1991) examined 6 elk skeletons and devised a chart relating age with epiphyseal fusion in long bones and phalanges. The Tope Elk must be at least 46 months old, based on the fully fused distal femur and distal metacarpal.

4) Though estimating the age (aging) of elk by tooth eruption and wear criteria is less accurate than other techniques, such as examination of the annuli of the cementum of incisor root tips (Hamlin et al. 2000), the eruption-wear criteria must be considered for the Tope Elk since no incisors are present. Several researchers have aged elk based on the eruption-wear criteria for cheek teeth (Murie 1951; Swanson 1951; Quimby and Gaab 1952; Jensen 1999). However, these studies use the mandibular dentition for aging rather than the upper dentition, due to the applicability of the former to field work with hunted animals (i.e., the incisors are readily visible and the lower dentition can be seen with a simple dissection). The mandibles are not present in the Tope Elk skeleton, but this specimen is much older than the 3 to 3.5-year-old Lattimer Elk, and according to Jensen (1999), elk 4.5 years and older are less reliable to age by tooth wear. Jensen (1999) also states that for the lower first molar the dentine nearly surrounds the infundibulum by 8.5 years of age, and in older individuals the infundibulum will be completely worn away. If extrapolated to the upper dentition, the first molar in the Tope Elk shows the infundibulum still present and not completely surrounded by dentine (Fig. 2). This would give an estimated age of approximately 8.5 years, and clearly more than 4 years. One of the 
Table 2

Inventory of Tope Elk skeletal remains

\begin{tabular}{|c|c|c|c|c|c|}
\hline Element & Side & Portion & Age & Taphonomy & Comments \\
\hline $\begin{array}{l}\text { Maxilla } \& \\
\text { premaxilla }\end{array}$ & $\mathrm{L}$ & Complete & Adult & & $\begin{array}{l}\text { With tooth row: PM2-4 and } \\
\text { M1-3; canine missing. Abscess } \\
\text { on mesiobuccal root of M3. } \\
\text { Alveolar resorption along PM \& } \\
\text { M tooth row. Large muscle scar } \\
\text { on maxilla. }\end{array}$ \\
\hline Maxilla & $\mathrm{R}$ & Partial & Adult & & $\begin{array}{l}\text { With PM2-4. Canine alveolus } \\
\text { not present. Darker stain but } \\
\text { same individual as L. maxilla. }\end{array}$ \\
\hline First molar & $\mathrm{R}$ & Complete & Adult & & $\begin{array}{l}\text { Re-fits with R. maxilla above. } \\
\text { Bone surrounding roots. }\end{array}$ \\
\hline Antler tine & $?$ & Complete & Adult & & $\begin{array}{l}\text { Large tine, broken off of main } \\
\text { beam. }\end{array}$ \\
\hline $\begin{array}{l}\text { 6th cervical } \\
\text { vertebra }\end{array}$ & N/A & Complete & Adult & $\begin{array}{l}\text { Missing ventral branch } \\
\text { of transverse process, } \\
\text { right side, and some } \\
\text { damage to cortex of } \\
\text { centrum, anterior } \\
\text { surface. All old breakage. }\end{array}$ & $\begin{array}{l}\text { Large muscle scars on dorsal } \\
\text { spine. Darker stain, same as seen } \\
\text { on R. maxilla. }\end{array}$ \\
\hline $\begin{array}{l}2 \text { nd thoracic } \\
\text { vertebra }\end{array}$ & $\mathrm{N} / \mathrm{A}$ & Complete & Adult & & $\begin{array}{l}\text { Pronounced muscle attachments, } \\
\text { on dorsal spine, zygapophyses, etc. }\end{array}$ \\
\hline $\begin{array}{c}\text { 3rd thoracic } \\
\text { vertebra }\end{array}$ & $\mathrm{N} / \mathrm{A}$ & Complete & Adult & $\begin{array}{l}\text { Some breakage to L. } \\
\text { transverse process (recent). }\end{array}$ & $\begin{array}{l}\text { Pronounced muscle attachments, } \\
\text { on dorsal spine, zygapophyses, etc. }\end{array}$ \\
\hline $\begin{array}{l}\text { 4th thoracic } \\
\text { vertebra }\end{array}$ & N/A & Complete & Adult & & $\begin{array}{l}\text { Pronounced muscle attachments, } \\
\text { on dorsal spine, zygapophyses, etc. }\end{array}$ \\
\hline Sacrum - S1-S4 & N/A & Complete & Adult & $\begin{array}{l}\text { Minor breakage to } \\
\text { anterior edges of wings of } \\
S 1 \text { (older and recent) and } \\
\text { to crest of } S 1 \text { (recent). }\end{array}$ & \\
\hline Scapula & $\mathrm{L}$ & Distal & Adult & $\begin{array}{l}\text { Breakage is old, but } \\
\text { scapular spine damage is } \\
\text { recent. }\end{array}$ & $\begin{array}{l}\text { Missing scapular spine, } 1 \text { fragment } \\
\text { present (below), and missing } \\
\text { supra- and infraspinous fossa. }\end{array}$ \\
\hline Scapular spine & $\mathrm{L}$ & Fragment & Adult & & Re-fits to distal scapula above. \\
\hline Metacarpal & $\mathrm{L}$ & Complete & Adult & & $\begin{array}{l}\text { Epiphyses fully fused. Pronounced } \\
\text { muscle attachment sites. }\end{array}$ \\
\hline $\begin{array}{l}\text { 2nd (middle) } \\
\text { phalanx }\end{array}$ & $?$ & Complete & Adult & & Proximal epiphysis fully fused. \\
\hline 3rd (distal) phalanx & $?$ & Complete & Adult & & \\
\hline 3rd (distal) phalanx & $?$ & Complete & Adult & & \\
\hline Innominate & $\mathrm{R}$ & Complete & Adult & Breakage appears recent. & $\begin{array}{l}\text { Missing posterior portion of } \\
\text { the symphyseal branch of the } \\
\text { pubis and symphyseal branch } \\
\text { of ischium. Some breakage to } \\
\text { anterior end of iliac crest. }\end{array}$ \\
\hline
\end{tabular}


Table 2 (continued)

Inventory of Tope Elk skeletal remains

\begin{tabular}{|c|c|c|c|c|c|}
\hline Element & Side & Portion & Age & Taphonomy & Comments \\
\hline Femur & $\mathrm{R}$ & Complete & Adult & & $\begin{array}{l}\text { Epiphyses fully fused. Pronounced } \\
\text { muscle attachment sites. }\end{array}$ \\
\hline Rib, ca. 7th & $\mathrm{L}$ & Complete & Adult & & $\begin{array}{l}\text { Pronounced muscle attachment } \\
\text { sites. }\end{array}$ \\
\hline Rib, ca. 11th & $\mathrm{R}$ & Complete & Adult & & $\begin{array}{l}\text { Pronounced muscle attachment } \\
\text { sites. }\end{array}$ \\
\hline Rib, ca. 12th & $\mathrm{L}$ & Complete & Adult & & $\begin{array}{l}\text { Pronounced muscle attachment } \\
\text { sites. }\end{array}$ \\
\hline Rib & $?$ & Fragment & Adult & & $\begin{array}{l}\text { Fragment of posterior rib, medial } \\
\text { surface. }\end{array}$ \\
\hline
\end{tabular}

Silver Lake Elk skeletons (specimen number 3) has wear on the upper dentition (similar to that of the Tope Elk), and the mandibles are present with this specimen. These mandibles exhibit a worn first molar with the infundibulum nearly surrounded by dentine and can be aged to the approximately 8.5-year category. Though wild elk can live over 20 years (Senseman 2002), Wisdom and Cook (2000) found that male elk in wild, non-hunted populations typically live less than 10 years. Thus, the Tope Elk was a full adult probably nearing the end of a typical lifespan for a male elk.

5) Alveolar bone resorption is seen in the Tope Elk along the lateral surface of the premolars and molars of the left maxilla and along the premolars in the right maxillary fragment. This is normal alveolar bone loss with aging, and is the same degree of resorption seen in the right maxilla of one of the similar-aged Silver Lake Elk (Goslin 1961). This would also suggest an age near the 8.5-year category. Also noted is considerable bone loss along the mesiobuccal root of the third molar in the left maxilla. Most of the root is exposed due to bone resorption along the buccal surface of the root, and pitting is seen along the length of the root. Porosity of the bone surrounding the mesiobuccal root, and pitting on the root, is suggestive of an abscess (Ortner and Putschar 1981).

6) No substantial signs of osteoarthritis were observed in the bones of the Tope Elk skeleton. Osteoarthritis does occur in large mammals in the wild, and has previously been reported in cervids, such as elk (Lyman 2010) and moose (Alces alces) (Peterson 1988), and also in wild horses (Wilson
2012). Lyman (2010) describes 2 pathologies in a partial skeleton of a large elk from the Marmes Rockshelter in Washington State. The individual had a form of spinal arthritis, diffuse idiopathic skeletal hyperostosis (DISH), in 2 cervical vertebrae and a pathology similar to osteoarthritis, spondylosis deformans, in 2 thoracic vertebrae. Lyman (2010) did not attempt to age the individual, probably because no cranial elements were found with the skeleton; however, he did deem it as a skeletally mature individual.

In the Tope Elk, the presence of pronounced muscle attachment sites and fully fused epiphyses, along with the lack of signs of idiopathic arthritis, help substantiate that the Tope Elk is a mature adult but not yet of advanced age.

The conclusion that the Tope Elk is a large, robust male was tested by comparing measurements of the Tope Elk to 2 of the Silver Lake Elk (specimens number 2 and number 3) (Table 3). These 2 Silver Lake skeletons were selected because of their completeness and that they-based on mandibular wear-are in the same 8.5-year age range as the Tope Elk. Silver Lake Specimen Number 2 is believed to be a male, but it's uncertain if one of the large antler pairs found in storage with the Silver Lake skeletons does, indeed, belong with this specimen. Silver Lake Specimen Number 3 is a male, based on antler pedicles on the frontal bones.

Twenty-five measurements were taken on Silver Lake Specimen Number 2, and when compared to the Tope Elk, $88 \%$ of the measurements were larger for the Tope Elk (Table 3). For Silver Lake Specimen Number 3, 29 measurements were taken 


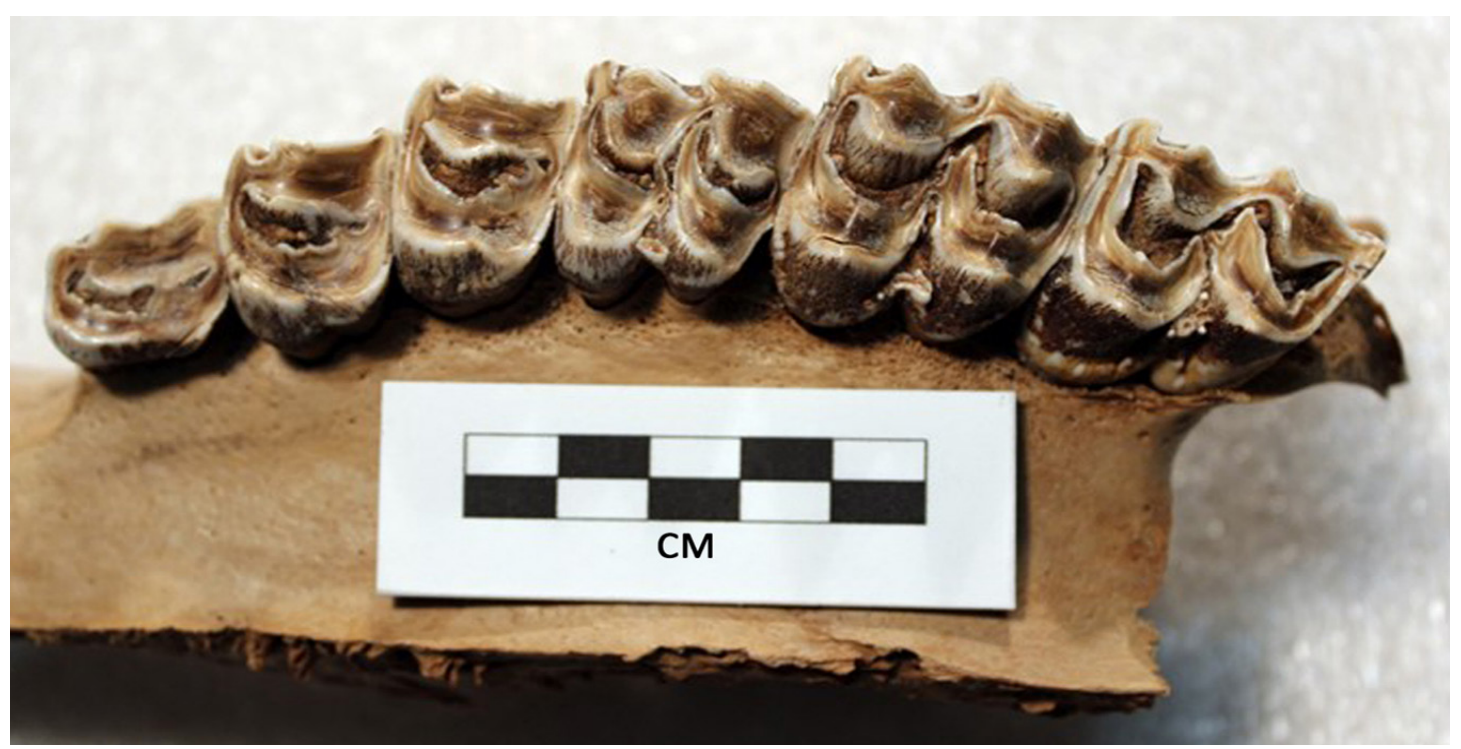

FIGURE 2. Upper left tooth row of the Tope Elk, with premolars 2 through 4 and molars 1 through 3 . Anterior on the left.

and $86.2 \%$ of the measurements were larger for the Tope Elk. This clearly demonstrates that the Tope Elk is larger and more robust than similar-aged elk skeletons. All measurements follow von den Driesch (1976). Muscle scars (entheses) were visually compared between the Tope Elk and the Silver Lake Elk Specimen Number 3, a similar-aged male, to assess robustness. Entheses were evaluated for 12 of the bones that were measured in Table 3, and in each case the entheses were more pronounced in the Tope Elk.

Some species of late Pleistocene mammals tended to be larger than their more recent counterparts (Guthrie 1984). Lyman (2010) notes that terminal Pleistocene elk in eastern Washington State grew to a very large size, greater than their modern counterparts, probably as a result of the high quality forage available at the time. Diminution in size has also been documented for Bison in the Great Plains of North America during the late Quaternary (Hill etal.2008), and also in areas peripheral to the center of their natural range (Lyman 2004). The greater size of the Tope Elk compared to the more modern Silver Lake Elk holds to this pattern of diminution since the late Pleistocene.

\section{Seasonality}

Barnosky (1985) studied another large cervid species, the extinct late Pleistocene Irish elk (Megaloceros giganteus) at Ballybetagh bog in Ireland. He concluded that within male groups, which were segregated from females during the winter, winterkill was the chief cause of death of individuals. He found that male Irish elk visited the bog more often than females during winters, and unfit individuals died and decomposed near the edge of the water. In general, male cervids are more likely to die during the winter than females because males eat less during the fall rut (CluttonBrock et al. 1982). Thus, the Tope Elk, a mature male as evidenced by the presence of a tine from a large antler, most likely died in the fall or winter when elk have fully grown antlers. Though a large individual, the Tope Elk could have been in declining health due to conditions not indicated on the skeleton and could not survive the winter.

\section{Accelerator Mass Spectrometry (AMS) Radiocarbon Dating}

The fragment of scapula from the Tope Elk returned an AMS radiocarbon age of 10,270 \pm 30 ${ }^{14} \mathrm{C}$ yr BP (Beta-477478) with a 2-sigma calibrated (Reimer et al. 2013) date range of 12,154 to 11,835 cal yr BP (C/N: 3.2; \%C: $42.25 ; \% \mathrm{~N}$ : 15.23 ; $\delta 13 \mathrm{C}:-21.1 \%$; $\delta 15 \mathrm{~N}: 4.1 \%$ o). The second radiocarbon assay on metacarpal bone resulted in a nearly identical age of $10,260 \pm 30{ }^{14} \mathrm{C}$ yr BP (Beta521748) and a 2-sigma calibrated date range of 12,144 to $11,830 \mathrm{cal}$ yr BP (C/N: 3.3 ; \%C: 41.72 ; $\% \mathrm{~N}: 14.93$; $\delta 13 \mathrm{C}:-21.0 \%$; $\delta 15 \mathrm{~N}: 4.0 \% 0)$. The 2 radiocarbon determinations for the Tope Elk remains are significantly older (Student's $t=139.65$, $\chi^{2}=3.84[0.05], \mathrm{df}=1$ ) than the Cranberry Prairie Elk, the next most ancient specimen in this group. These results place the Tope Elk in the terminal Pleistocene epoch, thereby predating all other directly dated specimens of Cervus canadensis in the region as discussed below. 
Table 3

Comparative metrics in $\mathrm{mm}$ (in) of Tope Elk and Silver Lake Elk remains

\begin{tabular}{|c|c|c|c|c|}
\hline Element & Measurement & Tope Elk & Silver Lake Elk No. 2 & Silver Lake Elk No. 3 \\
\hline $\begin{array}{l}\text { Left premaxilla and } \\
\text { maxilla }\end{array}$ & Greatest length & $304(11.9)$ & N/A & N/A \\
\hline Left maxilla & Lateral length & $134(5.3)$ & N/A & N/A \\
\hline Tooth row, upper left & Greatest length & $144(5.7)$ & N/A & $132(5.2)$ \\
\hline Antler tine & Length & $459(18.1)$ & N/A & N/A \\
\hline 6th cervical vertebra & $\begin{array}{l}\text { Greatest height } \\
\text { Greatest width }\end{array}$ & $\begin{array}{l}182(7.1) \\
122(4.8)\end{array}$ & $\begin{array}{l}158(6.2) \\
118(4.6)\end{array}$ & $\begin{array}{l}181(7.1) \\
124(4.9)\end{array}$ \\
\hline \multirow[t]{2}{*}{ 2nd thoracic vertebra } & Greatest height & $224(8.8)$ & $194(7.6)$ & $210(8.3)$ \\
\hline & $\begin{array}{l}\text { Greatest breadth of } \\
\text { body, with rib facets }\end{array}$ & $48(1.9)$ & $42(1.7)$ & $51(2.0)$ \\
\hline \multirow[t]{2}{*}{ 3rd thoracic vertebra } & Greatest height & $240(9.4)$ & $183(7.2)$ & $220(8.7)$ \\
\hline & $\begin{array}{l}\text { Greatest breadth of } \\
\text { body, with rib facets }\end{array}$ & $45(1.8)$ & $42(1.7)$ & $48(1.9)$ \\
\hline \multirow[t]{2}{*}{ 4th thoracic vertebra } & Greatest height & $231(9.1)$ & $184(7.2)$ & $211(8.3)$ \\
\hline & $\begin{array}{l}\text { Greatest breadth of } \\
\text { body, with rib facets }\end{array}$ & $48(1.9)$ & $45(1.8)$ & $45(1.8)$ \\
\hline \multirow[t]{3}{*}{ Sacrum - S1-S4 } & Greatest length & $202(8.0)$ & N/A & N/A \\
\hline & $\begin{array}{l}\text { Greatest breadth of } \\
\text { anterior articular } \\
\text { surface }\end{array}$ & $69(2.7)$ & $55(2.2)$ & $65(2.6)$ \\
\hline & $\begin{array}{l}\text { Greatest height of } \\
\text { anterior articular } \\
\text { surface }\end{array}$ & $28(1.1)$ & $25(1.0)$ & $27(1.1)$ \\
\hline \multirow[t]{2}{*}{ Left scapula } & $\begin{array}{l}\text { Greatest length of } \\
\text { glenoid }\end{array}$ & $72(2.8)$ & $69(2.7)$ & $76(3.0)$ \\
\hline & $\begin{array}{l}\text { Greatest breadth of } \\
\text { glenoid }\end{array}$ & $55(2.2)$ & $50(2.0)$ & $53(2.1)$ \\
\hline \multirow[t]{4}{*}{ Left metacarpal } & Greatest length & $270(10.6)$ & $271(10.7)$ & $278(11.0)$ \\
\hline & $\begin{array}{l}\text { Greatest breadth, } \\
\text { proximal }\end{array}$ & $50(2.0)$ & $46(1.8)$ & $50(2.0)$ \\
\hline & $\begin{array}{l}\text { Greatest breadth, } \\
\text { distal }\end{array}$ & $53(2.1)$ & $47(1.9)$ & $49(1.9)$ \\
\hline & $\begin{array}{l}\text { Least breadth of } \\
\text { diaphysis }\end{array}$ & $31(1.2)$ & $32(1.3)$ & $30(1.2)$ \\
\hline
\end{tabular}


Table 3 (continued) Comparative metrics in $\mathrm{mm}$ (in) of Tope Elk and Silver Lake Elk remains

\begin{tabular}{|c|c|c|c|c|}
\hline Element & Measurement & Tope Elk & Silver Lake Elk No. 2 & Silver Lake Elk No. 3 \\
\hline \multirow[t]{3}{*}{ 2nd (middle) phalanx } & Greatest length & $47(1.9)$ & N/A & $41(1.6)$ \\
\hline & $\begin{array}{l}\text { Greatest breadth } \\
\text { proximal }\end{array}$ & $26(1.0)$ & N/A & $24(0.9)$ \\
\hline & $\begin{array}{l}\text { Least breadth of } \\
\text { diaphysis }\end{array}$ & $20(0.8)$ & N/A & $18(0.7)$ \\
\hline \multirow{2}{*}{$\begin{array}{l}\text { 3rd (distal) phalanx } \\
\text {-specimen A }\end{array}$} & Greatest length & $56(2.2)$ & $49(1.9)$ & $58(2.3)$ \\
\hline & $\begin{array}{l}\text { Length of dorsal } \\
\text { surface }\end{array}$ & $54(2.1)$ & $45(1.8)$ & $52(2.0)$ \\
\hline \multirow{2}{*}{$\begin{array}{l}\text { 3rd (distal) phalanx } \\
\text {-specimen B }\end{array}$} & Greatest length & $55(2.2)$ & N/A & N/A \\
\hline & $\begin{array}{l}\text { Length of dorsal } \\
\text { surface }\end{array}$ & $54(2.1)$ & N/A & N/A \\
\hline \multirow[t]{2}{*}{ Right innominate } & $\begin{array}{l}\text { Length of acetabulum, } \\
\text { including lip }\end{array}$ & $74(2.9)$ & $66(2.6)$ & $70(2.8)$ \\
\hline & $\begin{array}{l}\text { Length of acetabulum } \\
\text { on rim }\end{array}$ & $52(2.0)$ & $54(2.1)$ & $52(2.0)$ \\
\hline \multirow[t]{5}{*}{ Right femur } & Greatest length & $381(15.0)$ & $361(14.2)$ & $377(14.8)$ \\
\hline & $\begin{array}{l}\text { Greatest breadth, } \\
\text { proximal }\end{array}$ & $118(4.6)$ & $105(4.1)$ & $112(4.4)$ \\
\hline & $\begin{array}{l}\text { Greatest breadth, } \\
\text { distal }\end{array}$ & $91(3.6)$ & $89(3.5)$ & $88(3.5)$ \\
\hline & $\begin{array}{l}\text { Least breadth of } \\
\text { diaphysis }\end{array}$ & $38(1.5)$ & $35(1.4)$ & $36(1.4)$ \\
\hline & $\begin{array}{l}\text { Greatest width of } \\
\text { femoral head }\end{array}$ & 47 (1.9) & $45(1.8)$ & 47 (1.9) \\
\hline
\end{tabular}

Table 4

Elk remains directly dated by radiocarbon

\begin{tabular}{|c|c|c|c|c|}
\hline Site name & Lab. No. & ${ }^{14} \mathrm{C}$ age & $2 \sigma$ calibrated age range & Reference \\
\hline Mohawk Pool, NY & Beta-197896 & $8,340 \pm 70$ yr BP & $9,489-9,135$ cal yr BP & Laub 2009: p. 39 \\
\hline Hiscock, NY & CAMS-27142 & $8,620 \pm 50$ yr BP & $9,698-9,521 \mathrm{cal} \mathrm{yr} \mathrm{BP}$ & Laub 2003: p. 37 \\
\hline Lattimer Farm, $\mathrm{OH}$ & -- & $9,020 \pm 60$ yr BP & $10,272-9,920 \mathrm{cal} \mathrm{yr} \mathrm{BP}$ & Hansen 1996: p. 5 \\
\hline Cranberry Prairie, $\mathrm{OH}$ & DIC-2555 & $9,370 \pm 70$ yr BP & $10,769-10,301 \mathrm{cal} \mathrm{yr} \mathrm{BP}$ & $\begin{array}{l}\text { Murphy et al. } \\
\text { 1985: p. } 113\end{array}$ \\
\hline Tope Elk, OH & Beta-521748 & $10,260 \pm 30$ yr BP & $12,144-11,830 \mathrm{cal} \mathrm{yr} \mathrm{BP}$ & This article \\
\hline Tope Elk, OH & Beta -477478 & $10,270 \pm 30$ yr BP & $12,154-11,835 \mathrm{cal}$ yr BP & This article \\
\hline
\end{tabular}




\section{DISCUSSION}

Only 5 directly dated elk specimens of late Pleistocene to early Holocene age are known for the eastern woodlands, and these come from the states of Ohio and New York (Table 4, above). The radiocarbon assays demonstrate that Cervus canadensis was resident in at least the southern Great Lakes area during the final millennium of the terminal Pleistocene (ca. 12,500 to 11,500 cal yr BP), a time frame that overlaps with the Younger Dryas event (ca. 12,900 to $11,700 \mathrm{cal} \mathrm{yr}$ BP) (Alley 2000; Carlson 2013) and the demise of the remaining North American megafauna (Faith and Surovell 2009).

The extinct stag-moose (Cervalces scotti) is another large cervid from the late Pleistocene of Ohio. All known Ohio dates for this species range from 15,705 to 11,345 cal yr BP $(12,840 \pm 100$ to $10,230 \pm 150{ }^{14} \mathrm{C}$ yr BP) (Glotzhober and McDonald 2015: Table 2), indicating that the stagmoose largely predated elk in Ohio. Cervalces has typically been associated with spruce forests and its local extinction in Ohio, with subsequent increase in Cervus, can be correlated with the decline in Picea and increase in deciduous vegetation (McDonald 1989; Gill et al. 2012).

Recent calculations of "last appearance" dates for proboscideans such as the Overmyer Mastodon (Mammut americanum) in Indiana (11,801 to 11,330 cal yr BP) (Woodman and Athfield 2009: Table 1) suggest that the Cervus canadensis may have co-existed for several centuries with this species. A more recent study of proboscidean ages (including re-dating of the Overmyer specimen), however, points to the likely extinction of mammoth and mastodon in the midcontinent by ca. $12,500 \mathrm{cal}$ yr BP (Widga et al. 2017). Yet, another analysis proposes the demise of mastodon in New York State between 12,460 and 11,930 cal yr BP, and even later for mammoth at 12,240 to 10,190 cal yr BP (Feranec and Kozlowski 2016: Table 1). These various results strongly indicate that the Tope Elk existed within just a few centuries, if not as a contemporary, of the last vestiges of ice age megafauna.

The late Pleistocene environment in the Ohio region was a time of significant habitat change (Shane 1987; Shane and Anderson 1993). Recent pollen data from glacial lakes in northeast Ohio indicate the continued decline of spruce-fir (boreal) forest on the Allegheny Plateau after ca. 12,000 cal yr BP and establishment of pine woodland during the latter half of the Younger Dryas (Swisher and Peck 2020). The correlation of this environmental shift away from spruce parkland with the timing of the Tope Elk make sense given the woodland habitat preferences of historic eastern elk (Cervus canadensis canadensis) (O'Gara and Dundas 2002).

Finally, the terminal Pleistocene witnessed the earliest human (Paleoindian) presence in the eastern woodlands (ca. 13,000 to $11,200 \mathrm{cal} \mathrm{yr}$ BP) (Waters and Stafford 2007; Ellis et al. 2011). The temporal position of the Tope Elk skeleton places the appearance of this species in Ohio several centuries after the arrival of the first Clovis colonizers of northern Ohio (ca. 13,000 to 12,700 cal yr BP) (Brose 1994: p. 65; Eren et al. 2018: p. 189) and during the Late Paleoindian period $(12,048$ to $11,192 \mathrm{cal}$ yr BP) (Ellis et al. 2011). Even though the Tope Elk exhibits no evidence of direct human predation, its availability at such an early date would have made it a new, viable prey species for early hunters.

\section{Conclusions}

The analysis and dating of the Tope Elk show a greater antiquity for this species in eastern North America than previously documented. This is the first directly dated record of elk in the terminal Pleistocene of Ohio. The morphological characteristics of the remains reveal the presence of robust males of large proportions at this early time and provide evidence suggesting diminution of this species through the Holocene. This discovery also provides the first direct chronological evidence for the presence of elk in the region just a few centuries after the extinction of most late Pleistocene megafauna, but contemporary with Late Paleoindian foragers.

\section{ACKNOWLEDGEMENTS}

The authors are grateful to the Tope family for their discovery of the elk remains and subsequent donation of the collection to the Cleveland Museum of Natural History. Funding for the 2 radiocarbon dates was provided by the Cleveland Museum of Natural History. Helpful comments on this paper were received from $\mathrm{H}$. Gregory McDonald and 4 anonymous reviewers. 


\section{LITERATURE CITED}

Adovasio JM, Gunn JD, Donahue J, Stuckenrath R. 1978. Meadowcroft Rockshelter, 1977: an overview. Am Antiquity. 43(4):632-651. https://doi.org/10.2307/279496

Alley RB. 2000. The Younger Dryas cold interval as viewed from central Greenland. Quaternary Sci Rev. 19(1-5):213-226. https://doi.org/10.1016/S0277-3791(99)00062-1

Barnosky AD. 1985. Taphonomy and herd structure of the extinct Irish elk, Megaloceros giganteus. Science. 228(4697):340-344.

https://doi.org/10.1126/science.228.4697.340

Brose DS. 1994. Archaeological investigations at the Paleo Crossing site, a Paleoindian occupation in Medina County, Ohio. In: Dancey WS, editor. The first discovery of America: archaeological evidence of the early inhabitants of the Ohio area. Columbus $(\mathrm{OH})$ : Ohio Archaeological Council. p. 61-76. ISBN13: 9780964239104.

Burns JA. 2010. Mammalian faunal dynamics in late Pleistocene Alberta, Canada. Quatern Int. 217(1-2):37-42. https://doi.org/10.1016/j.quaint.2009.08.003

Carlson AE. 2013. Paleoclimate | The Younger Dryas climate event. In: Elias SA, Mock CJ, editors. Encyclopedia of Quaternary science. 2nd ed. Amsterdam (NL): Elsevier. p. 126-134. https://doi.org/10.1016/B978-0-444-53643-3.00029-7

Cleland CE. 1966. The prehistoric animal ecology and ethnozoology of the upper Great Lakes region. Ann Arbor (MI): University of Michigan Press. 306 p. Anthropological Papers 29, Museum of Anthropology, University of Michigan.

https://doi.org/10.3998/mpub.11396632

Clutton-Brock TH, Guinness FE, Albon SD. 1982. Red deer: behavior and ecology of two sexes. Chicago (IL): University of Chicago Press. 378 p. ISBN13: 9780226110578.

Ellis CJ, Carr DH, Loebel TJ. 2011. The Younger Dryas and late Pleistocene peoples of the Great Lakes region. Quatern Int. 242(2):534-545.

https://doi.org/10.1016/j.quaint.2011.02.038

Eren MI, Redmond BG, Miller GL, Buchanan B, Boulanger MT, Morgan BM, O’Brien MJ. 2018. Paleo Crossing (33ME274): a Clovis site in northeastern Ohio. In: Gingerich JAM, editor. In the eastern fluted point tradition, volume II. Salt Lake City (UT): University of Utah Press. p. 187-210. ISBN13: 9781607815792.

Eshelman RE, Lowery D, Grady F, Wagner D, McDonald HG. 2018. Late Pleistocene (Rancholabrean) mammalian assemblage from Paw Paw Cove, Tilghman Island, Maryland. Washington (DC): Smithsonian Institution Scholarly Press. 16 p. Smithsonian Contributions to Paleobiology Number 102.

https://doi.org/10.5479/si.1943-6688.102

Faith JT, Surovell TA. 2009. Synchronous extinction of North America's Pleistocene mammals. P Natl Acad Sci USA. 106(49):20641-20645.

https://doi.org/10.1073/pnas.0908153106
Feranec RS, Kozlowski AL. 2016. Implications of a Bayesian radiocarbon calibration of colonization ages for mammalian megafauna in glaciated New York State after the Last Glacial Maximum. Quaternary Res. 85(2):262-270.

https://doi.org/10.1016/j.yqres.2016.01.003

Fonda SS, Czebieniak AP. 1986. Late Pleistocene fauna of the Hollidaysburg Fissure. In: McDonald JN, Bird SO, editors. The Quaternary of Virginia: a symposium volume. Charlottesville (VA): Commonwealth of Virginia, Department of Mines, Minerals and Energy, Division of Mineral Resources. p. 128-129. Virginia Division of Mineral Resources Publication 75.

Gill JL, Williams JW, Jackson ST, Donnelly JP, Schellinger GC. 2012. Climatic and megaherbivory controls on late-glacial vegetation dynamics: a new, high-resolution, multi-proxy record from Silver Lake, Ohio. Quaternary Sci Rev. 34:66-80. https://doi.org/10.1016/j.quascirev.2011.12.008

Glotzhober RC, McDonald HG. 2015. Partial skeleton of an elk-moose, Cervalces scotti, from Chippewa Lake, Medina County, Ohio. PaleoAmerica. 1(4):332-342. https://doi.org/10.1179/2055557115Y.0000000008

Goslin RM. 1961. Projectile point in elk skeleton. Ohio Archaeologist. 11(3):84-85.

Guilday JE. 1967. The climatic significance of the Hosterman's Pit local fauna, Centre County, Pennsylvania. Am Antiquity. 32(2):231-232. https://doi.org/10.2307/277912

Guilday JE, Hamilton HW, Anderson E, Parmalee PW. 1978. The Baker Bluff cave deposit, Tennessee, and the late Pleistocene faunal gradient. Bulletin of Carnegie Museum of Natural History. 11:1-67.

Guilday JE, Parmalee PW, Hamilton HW. 1977. The Clark's Cave bone deposit and the late Pleistocene paleoecology of the central Appalachian Mountains of Virginia. Bulletin of Carnegie Museum of Natural History. 2:1-87.

Gustafson CE, Wegener RM. 2004. Faunal remains. In: Hicks BA, editor. Marmes Rockshelter: a final report on 11,000 years of cultural use. Pullman (WA): Washington State University Press. p. 253-317. ISBN13: 9780874222753.

Guthrie RD. 1984. Alaskan megabucks, megabulls, and megarams: the issue of Pleistocene gigantism. In: Genoways $\mathrm{HH}$, Dawson MR, editors. Contributions in Vertebrate Paleontology, Carnegie Museum of Natural History Special Publication 8, Pittsburgh. p. 482-510.

Hamlin KL, PacDF, Sime CA, DeSimone RM, Dusek GL. 2000. Evaluating the accuracy of ages obtained by two methods for Montana ungulates. J Wildlife Manage. 64(2):441-449. https://doi.org/10.2307/3803242

Hansen MC. 1996. Ohio elk. Ohio Geology. Spring:4-6. A quarterly publication [newsletter] of the Ohio Department of Natural Resources, Division of Geological Survey. Publication Series: OGN 1996-SP.

https://ohiodnr.gov/static/documents/geology/OGN_1996_n4Spring.pdf 
Hill ME Jr, Hill MG, Widga CC. 2008. Late Quaternary Bison diminution on the Great Plains of North America: evaluating the role of human hunting versus climate change. Quaternary Sci Rev. 27(17-18):1752-1771. https://doi.org/10.1016/j.quascirev.2008.07.002

Jensen W. 1999. Aging elk. North Dakota Outdoors. August:16-20. Official publication of the North Dakota Game and Fish Department.

https:/gf.nd.gov/sites/default/files/publications/aging-elk.pdf

Johnson E. 1985. Current developments in bone technology. In: Schiffer MB, editor. Advances in archaeological method and theory. Vol. 8. Orlando (FL): Academic Press. p. 157-235. https://doi.org/10.1016/B978-0-12-003108-5.50010-5

Kirtland JP. 1838. Report on the zoology of Ohio. In: Mather WW, principal geologist. Second annual report on the geological survey of the State of Ohio. Columbus $(\mathrm{OH})$ : Samuel Medary, printer to the State. p. 157-200. https://hdl.handle.net/2027/osu.32435062090642

Laub RS. 2003. The Hiscock Site: structure, stratigraphy and chronology. Bull Buffalo Soc Nat Sci. 37:18-38.

Laub RS. 2009. New data on Holocene fossil mammal occurrences at the Hiscock Site and its environs, western New York State. Bull Buffalo Soc Nat Sci. 38:33-42.

Laub RS, DeRemer MF, Dufort CA, Parsons WL. 1988. The Hiscock Site: a rich late Quaternary locality in western New York State. Bull Buffalo Soc Nat Sci. 33:67-81.

Lyman RL. 1991. Prehistory of the Oregon coast: the effects of excavation strategies and assemblage size on archaeological inquiry. San Diego (CA): Academic Press. 391 p. ISBN13: 9780124604155.

Lyman RL. 2004. Late-Quaternary diminution and abundance of prehistoric bison (Bison sp.) in eastern Washington State, USA. Quaternary Res. 62(1):76-85. https://doi.org/10.1016/j.yqres.2004.04.001

Lyman RL. 2010. Taphonomy, pathology, and paleoecology of the terminal Pleistocene Marmes Rockshelter (45FR50) "big elk" (Cervus elaphus), southeastern Washington State, USA. Can J Earth Sci. 47(11):1367-1382. https://doi.org/10.1139/E10-059

Lyon MW Jr. 1931. A small collection of Pleistocene mammals from Laporte County, Indiana. Am Midl Nat. 12(10):406-410. https://doi.org/10.2307/2420140

McDonald HG. 1989. New records of the elk-moose Cervalces scotti from Ohio. Am Midl Nat. 122(2):349-356. https://doi.org/10.2307/2425922

Murie OJ. 1951. The elk of North America. Lanham (MD): Stackpole Books. 376 p. ISBN: 9780811737227.

Murphy JL, Dyer DL, Walker DA. 1985. Prehistoric elk remains from Cranberry Prairie, Mercer County, Ohio. Ohio J Sci. 85(3):112-115. http://hdl.handle.net/1811/23073

O'Gara BW, Dundas RG. 2002. Distribution: past and present. In: Toweill DE, Thomas JW, editors. North American elk: ecology and management. Washington (DC): Smithsonian Institution Press. p. 67-119. ISBN 13: 9781588340184.
Ogden JG 3rd. 1966. Forest history of Ohio. I. Radiocarbon dates and pollen stratigraphy of Silver Lake, Logan County, Ohio. Ohio J Sci. 66(4):387-400. http://hdl.handle.net/1811/5200

Ortner DJ, Putschar WGJ. 1981. Identification of pathological conditions in human skeletal remains. Smithsonian Contributions to Anthropology number 28. https://doi.org/10.5479/si.00810223.28.1

Peterson RO. 1988. Increased osteoarthritis in moose from Isle Royale. J Wildlife Dis. 24(3):461-466. https://doi.org/10.7589/0090-3558-24.3.461

Quimby DC, Gaab JE. 1952. Preliminary report on a study of elk dentition as a means of determining age classes. Proceedings Western Association of State Game and Fish Commissioners. 32:225-227. https://hdl.handle.net/2027/umn.31951t00225995n

Reimer PJ, Bard E, Bayliss A, Beck JW, Blackwell PG, Ramsey CB, Buck CE, Cheng H, Edwards RL, Friedrich M, et al. 2013. IntCal13 and Marine13 radiocarbon age calibration curves 0-50,000 years cal BP. Radiocarbon. 55(4):1869-1887. https://doi.org/10.2458/azu_js_rc.55.16947

Schultz CB, Tanner LG, Whitmore FC Jr, Ray LL, Crawford EC. 1963. Paleontologic investigations at Big Bone Lick State Park, Kentucky: a preliminary report. Science. 142(3596):1167-1169.

https://doi.org/10.1126/science.142.3596.1167

Semken HA Jr, Graham RW, Stafford TW Jr. 2010. AMS ${ }^{14} \mathrm{C}$ analysis of late Pleistocene non-analog faunal components from 21 cave deposits in southeastern North America. Quatern Int. 217(1-2):240-255.

https://doi.org/10.1016/j.quaint.2009.11.031

Senseman R. 2002. Cervus canadensis. Animal Diversity Web. [Accessed 2019 Feb 04]. https://animaldiversity.org/accounts/Cervus_elaphus/

Shane LCK. 1987. Late-glacial vegetational and climatic history of the Allegheny Plateau and the Till Plains of Ohio and Indiana, U.S.A. Boreas. 16(1):1-20. https://doi.org/10.1111/j.1502-3885.1987.tb00750.x

Shane LCK, Anderson KH. 1993. Intensity, gradients and reversals in late glacial environmental change in east-central North America. Quaternary Sci Rev. 12(5):307-320. https://doi.org/10.1016/0277-3791(93)90039-O

Stuiver M, Reimer PJ. 1993. Extended ${ }^{14} \mathrm{C}$ data base and revised CALIB $3.0{ }^{14} \mathrm{C}$ age calibration program. Radiocarbon. 35(1):215-230. https://doi.org/10.1017/S0033822200013904

Swanson CV. 1951. A technique for age determination of elk (Cervus canadensis). Murrelet. 32(2):19-22. https://doi.org/10.2307/3535627

Swisher SE, Peck JA. 2020. Vegetation changes associated with the Younger Dryas from the sediments of Silver Lake, Summit County, Ohio, USA. Ohio J Sci. 120(2):30-38. https://doi.org/10.18061/ojs.v120i2.7095 
von den Driesch A. 1976. A guide to the measurement of animal bones from archaeological sites. Cambridge(MA): Harvard University Press. 145 p. Peabody Museum Bulletin 1. ISBN13: 9780873659505.

Waters MR, Stafford TW Jr. 2007. Redefining the age ofClovis: implications for the peopling of the Americas. Science. 315(5815):1122-1126.

https://doi.org/10.1126/science.1137166

Widga C, Lengyel SN, Saunders J, Hodgins G, Walker JD, Wanamaker AD. 2017. Late Pleistocene proboscidean population dynamics in the North American midcontinent. Boreas. 46(4):772-782.

https://doi.org/10.1111/bor.12235

Williams JW, Grimm EC, Blois JL, Charles DF, Davis EB, Goring SJ, Graham RW, Smith AJ, Anderson M, ArroyoCabrales J, Ashworth AC, Betancourt JL, Bills BW, et al. 2018. The Neotoma Paleoecology Database, a multiproxy, international, community-curated data resource. Quaternary Res. 89(1):156-177.

https://doi.org/10.1017/qua.2017.105
Willis DW, Scalet CG, Flake LD. 2009. Introduction to wildlife and fisheries: an integrated approach. 2nd ed. New York (NY): W.H. Freeman and Co. 461 p. ISBN 13: 9781429204460.

Wilson DA, editor. 2012. Clinical veterinary advisor: the horse. St. Louis (MO): Elsevier Saunders. 1104 p. ISBN 13: 9781416099796.

Wisdom MJ, Cook JG. 2000. North American elk. In: Demarais $S$, Krausman PR, editors. Ecology and management of large mammals in North America. Upper Saddle River (NJ): Prentice Hall. p. 694-735. ISBN 13: 9780137174225.

Woodman N, Athfield NB. 2009. Post-Clovis survival of American mastodon in the southern Great Lakes region of North America. Quaternary Res. 72(3):359-363.

https://doi.org/10.1016/j.yqres.2009.06.009 